\title{
Measuring Electronic Readiness of Extension Personnel in Assiut Governorate
}

\author{
Mohamed F. S. Abdel-Salam ${ }^{1}$ and Mohamed M. M. Abdel-Ghany ${ }^{2}$
}

\begin{abstract}
This study aimed to measure electronic readiness (Ereadiness) of extension personnel in Assiut governorate for utilizing ICTs in agricultural extension. The study used the three components determined by Bilbao-Osorio et al. (2014) in order to measure extension personnel' Ereadiness in Assiut governorate. Data were collected by using questionnaire from 117 personnel representing $39.6 \%$ of the total number of extension personnel in Assiut governorate (295 Personnel). The results showed a low Ereadiness of the respondents for utilizing ICTs in agricultural extension; which is supported by the low scores of the three components (infrastructure and digital content, the respondents' affordability to utilize ICTs in agricultural extension in Assiut governorate, and the respondents' skills in ICTs).
\end{abstract}

Keywords: E- Readiness, Agricultural Extension, ICTs

\section{INTRODUCTION}

During the last decade, many leaders in government, business, and social organizations around the world had considered how best to harness the power of information and communication technology (ICT) for development. Measuring E-readiness is meant to guide development efforts by providing benchmarks for comparison and measuring progress. Several Ereadiness initiatives have been launched to help developing countries in this area, and numerous Ereadiness assessment tools have been created and used by different groups (The World Bank, 2005).

Many of the transitions that happened in the agricultural sector around the world results from forces that are driving agriculture today like: climate change, changes in natural resources quality, lack of coping strategies at micro and macro levels of decision making, globalization, the emerging market forces and sustainability constraints. Information Communication Technologies (ICTs) can help in enabling extension workers to gather, store, retrieve, adapt, localize and disseminate a broad range of information needed by farmers (Meera, et al., 2010).

Egypt has landed in the 91st position, out of 144 countries, in the 2014 global information technology report, declining 11 positions compared to the previous year. The report also noted that Egypt has slightly improved in the individual information and communications technology (ICT); however, it was smaller than the improvement experienced by other countries (Bilbao- Osorio et al., 2014).

In Egypt, many of ICT projects had been implemented for example: virtual extension and research communication network (VERCON), and rural and agricultural development communication network (RADCON). These projects were funded temporary by international organizations. After the termination of fund, these projects had been stopped. This situation creates the need for studying E-readiness of extension personnel to utilize ICTs in agricultural extension.

\section{Objectives}

The main objective of this study is to measure Ereadiness of extension personnel in Assiut governorate through reaching the following sub-objectives:

(1) Knowing about the ICT's infrastructure of agricultural extension in Assiut governorate from the points of views of extension personnel.

(3) Identifying the respondents' affordability to utilize ICTs in agricultural extension in Assiut governorate.

(2) Determining the ICTs' skills of extension personnel in Assiut governorate.

\section{Literature Review}

\section{E-Readiness: Concept and Importance}

E-readiness concept refers to a nation's inventory of ICT resources for operating in a modern information society, and it is a measure of the quality of a country's ICT infrastructure and the ability of its consumers to use ICT for their benefit (Addom, 2004; Economist Intelligence Unit, 2009). The definition of E-readiness as given by the international development center at Harvard university describes an 'E-ready' society as one that has the necessary physical infrastructure, and has integrated current ICTs throughout businesses (commerce, local ICT sector), communities (local content, organizations online, ICTs used in everyday life, ICTs taught in schools), and the government (egovernment) (Addom, 2004).

E-readiness can be classified according to the level of measurement to three levels: (1) Individual Ereadiness: the degree to which an individual is able to use and access the ICT tools and has the necessary skills

\footnotetext{
${ }^{1}$ Department of Agricultural Extension \& Rural Sociology,

Faculty of Agriculture, Al-Azhar University, Assiut

${ }^{2}$ Department of Rural Sociology \& Agricultural Extension,

Faculty of Agriculture, Assiut University

Received March 25, 2015, Accepted June 10, 2015
} 
to get himself/herself updated with the technological developments. (2) Institutional E-readiness: the degree to which an institution possesses infrastructure, network accessibility, policy support and affordability to acquire and effectively utilize ICTs. Also it should possess sufficient skilled manpower to efficiently and effectively utilize the available ICT infrastructure. (3) National E-readiness: the degree to which a nation possesses necessary infrastructure, internet accessibility, affordability, policy support and the human resource with necessary skills to acquire, access, utilize ICTs (Jirli, et al., 2012).

The E-readiness process comprises four steps: (1) Choosing an appropriate assessment tool based on a clear understanding of national goals for ICT integration. (2) Conducting the E-readiness assessment. (3) Developing a detailed action plan that will move the country toward its objectives. (4) Implementing the plan (The World Bank, 2005).

The concept of E-readiness is important because its level can be a strong predictor of how well a country can perform in the new economy. An E-readiness assessment would provide policy makers with a detailed scorecard of their economy's competitiveness relative to its international counterparts. Further, a breakdown of indicators allows policy analysts to pinpoint areas of strengths and weaknesses, thus providing a balanced perspective in guiding a country through the digital transformation (Bui et al., 2003).

\section{Measuring E-Readiness}

Realizing the importance of E-readiness measurement and its implications for economic planning, many governmental and world organizations have created instruments either in the form of selfassessment tools or surveys (Bui et al., 2003).

One of the most prominent of these organizations is "World Economic Forum"; it publishes the global information technology report continuously since 2002 . This report provides a comprehensive assessment of Ereadiness, or how prepared an economy is to apply the benefits of information and communications technologies (ICTs) to promote economic growth and well-being.

The last global information technology report published in 2014 by World Economic Forum and edited by Bilbao-Osorio et al. have determined three components (Fig.1) for measuring E-readiness to make good use of ICTs as follows:

(1) The infrastructure and digital content component (five variables): it captures the development of ICT infrastructure including mobile network coverage, international internet bandwidth, secure internet servers, electricity production and the accessibility of digital content.

(2) The affordability component (three variables): it assesses the cost of accessing ICTs, either via mobile telephony or fixed broadband internet, as well as the level of competition in the internet and telephony sectors that determine this cost.

(3) The skills component (four variables): it gauges the ability of a society to make effective use of ICTs thanks to the existence of basic educational skills captured by the quality of the educational system, the level of adult literacy, and the rate of secondary education enrollment.

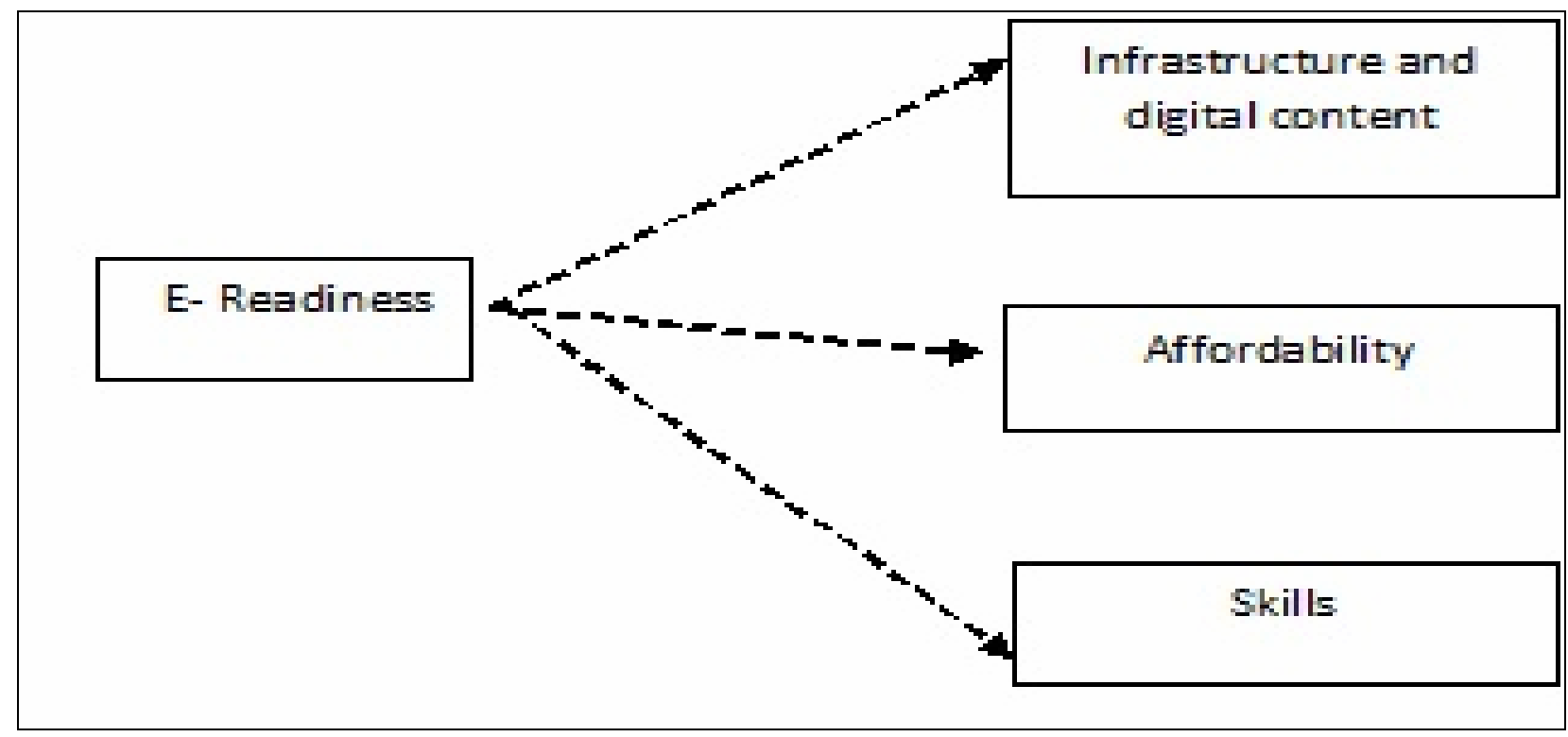

Figure 1. E-readiness components (Bilbao- Osorio et al., 2014) 


\section{Methodology}

This study used the three components determined by Bilbao-Osorio et al. (2014) in order to measure extension personnel' E-readiness in Assiut governorate for utilizing ICTs in agricultural extension.

The infrastructure and digital content component was assessed using five indicators: mobile network coverage in extension residence, electric source in extension residence, computer in extension residence, internet services in extension residence, digital production. The affordability component, this component was calculated by three indicators: costs of communication, costs of internet access and use, and costs of hardware and software. The skills component was captured by determining five skills of ICTs: general windows skills, word processing, internet, data base, and presentations (Abdel-Maksoud and Abdel-al, 2008; Gregg and Irani, 2004). Then, the respondents' training needs in these skills were assessed by using the Modified Delta N method (Abdel-Maksoud, 2010). The following formula was used to measure extension personnel's skills in ICTs: Extension personnel's skills in ICTs $=1$ - training needs in ICTs.
Questionnaire forms were prepared and distributed among extension personnel in the Assiut governorate. The total number of completed forms was 117 or $39.6 \%$ of the total number of extension personnel in this Governorate (295 Personnel). Data were collected from November to December 2014 by questionnaire. SPSS was used for data processing and analysis. Frequencies, percentages, and mean scores were used for data presentation.

\section{RESULTS AND DISCUSSION}

\section{The personal characteristics of the respondents}

Table (1) shows the distribution of the respondents according to their personal characteristic, it can be noticed that the majority of respondents $(72.7 \%)$ were aged 50 years and above, and less than two thirds of them $(65 \%)$ hold diploma of agricultural secondary schools. More than half of them $(59.8 \%$ ) have 30 years and above of work experience in agriculture, and 53\% of them have 10 years to less than 20 years of work experience in agricultural extension. More than half of the respondents $(51.3 \%)$ don't have personal computers, and $59 \%, 56.4 \%$ hear and don't work for VERCON and RADCON respectively. The majority of them $(82.1 \%)$ have never attended any training courses on ICTs.

Table 1. Distribution of the respondents according to their personal characteristics $(N=117)$

\begin{tabular}{llcc}
\hline Characteristics & Category & F & \% \\
\hline \multirow{2}{*}{ Age } & Below 40 years & 10 & 8.5 \\
& $40-$ & 22 & 18.8 \\
\hline \multirow{2}{*}{ Qualification } & 50 years and above & 85 & 72.7 \\
\hline \multirow{2}{*}{ Work experience in Agriculture } & Diploma of agric. Second. Schools & 76 & 65 \\
& B. SC. & 41 & 35 \\
\hline \multirow{3}{*}{ Work experience in Extension } & Less than 10 years & 7 & 6.0 \\
& $10-$ & 17 & 14.5 \\
& $20-$ & 23 & 19.7 \\
Having Computer & 30 years and above & 70 & 59.8 \\
\hline \multirow{2}{*}{ Hearing of and Work in VERCON } & Less than 10 years & 21 & 17.9 \\
& $10-$ & 62 & 53 \\
& $20-$ & 31 & 26.5 \\
& 30 years and above & 3 & 2.6 \\
\hline \multirow{2}{*}{ Hearing of and Work in RADCON } & No & 60 & 51.3 \\
& Yes & 57 & 48.7 \\
\hline \multirow{2}{*}{ ICTs Training Courses } & Never hear about it & 41 & 35.0 \\
& Work for it & 69 & 59.0 \\
\hline
\end{tabular}

Source: Questionnaire forms 


\section{The respondents' E-readiness}

\subsection{ICT's infrastructure of agricultural extension in} Assiut governorate

The distribution of the respondents according to their perceptions of ICT's infrastructure of agricultural extension in Assiut governorate is presented in table (2). The majority of the respondents have viewed that agricultural extension in Assiut governorate had a good infrastructure in two out of five indicators (mobile network coverage in extension station, and electric source in extension residence), while the majority of them had the opposite opinion about the remaining three indicators (computer in extension residence, internet services in extension residence, and digital production). The same table indicates that the infrastructure and digital content total score ranged between 0.94 as the highest score in the item of availability of electricity source in extension residence, and 0.13 as the lowest score in the item of accessing digital production. This result point out that agricultural extension in Assiut governorate doesn't have a good infrastructure from the respondents' point of view; thus, this component implies a weak E-readiness status of extension personnel in Assiut governorate.

2.2. The respondents' affordability to utilize ICTs in agricultural extension in Assiut governorate

Table (3) shows the respondents' affordability to utilize ICTs in agricultural extension in Assiut governorate. The total score ranged between 0.53 as the highest score in the item of communication costs in rural areas, and 0.48 as the lowest score in the item of hardware and software costs.

\subsection{The respondents' ICTs skills}

The respondents' ICTs skills are shown in table (4). The respondents' skills scores ranged between 0.4350 as the highest score in windows (the lowest training needs score), and 0.3205 as the lowest score in preparing presentations (the highest training needs score). This result indicates that the respondents are in need of more training in presentations and data base.

Table 2. ICT's infrastructure of agricultural extension in Assiut governorate as perceived by the respondents $(\mathrm{N}=117)$

\begin{tabular}{lccccc}
\hline \multirow{2}{*}{ Items } & \multicolumn{3}{c}{ The respondents' perceptions } \\
\cline { 2 - 5 } & \multicolumn{2}{c}{ Yes } & \multicolumn{2}{c}{ No } & \multicolumn{2}{c}{$\begin{array}{c}\text { Infrastructure } \\
\text { Score }\end{array}$} \\
\cline { 2 - 5 } & $\mathbf{F}$ & $\mathbf{\%}$ & $\mathbf{F}$ & $\mathbf{\%}$ & 0.77 \\
\hline Mobile network coverage in extension residence & 90 & 76.9 & 27 & 23.1 & 0.94 \\
\hline Electric source in extension residence & 110 & 94.0 & 7 & 6.0 & 0.29 \\
\hline Computer in extension residence & 34 & 29.1 & 83 & 70.9 & 0.15 \\
\hline Internet services in extension residence & 17 & 14.5 & 100 & 85.5 & 0.13 \\
\hline Digital production & 15 & 12.8 & 102 & 87.2 & \\
\hline
\end{tabular}

Table 3. The respondents' affordability to utilize ICTs in agricultural extension in Assiut governorate $(\mathrm{N}=117)$

\begin{tabular}{|c|c|c|c|c|c|c|c|}
\hline \multirow{3}{*}{ Items } & \multicolumn{6}{|c|}{ The respondents' affordability } & \multirow{3}{*}{$\begin{array}{c}\text { Affordability } \\
\text { Score }\end{array}$} \\
\hline & \multicolumn{2}{|c|}{ Never } & \multicolumn{2}{|c|}{ Sometime } & \multicolumn{2}{|c|}{ Always } & \\
\hline & $\mathbf{F}$ & $\%$ & $\mathbf{F}$ & $\%$ & $\mathbf{F}$ & $\%$ & \\
\hline Communication costs & 32 & 27.3 & 47 & 40.2 & 38 & 32.5 & 0.53 \\
\hline Internet access costs & 35 & 29.9 & 47 & 40.2 & 35 & 29.9 & 0.50 \\
\hline Hardware and software costs & 36 & 30.7 & 49 & 41.9 & 32 & 27.4 & 0.48 \\
\hline
\end{tabular}

Source: Questionnaire forms

Table 4. The respondents' skills in ICTs $(\mathrm{N}=117)$

\begin{tabular}{lccc}
\hline ICTs' skills & Training needs & Skill score & Rank \\
\hline Windows & 0.5650 & 0.4350 & 1 \\
\hline Internet & 0.5809 & 0.4191 & 2 \\
\hline Word Processing & 0.5908 & 0.4092 & 3 \\
\hline Data Base & 0.6766 & 0.3234 & 4 \\
\hline Presentation & 0.6795 & 0.3205 & 5 \\
\hline
\end{tabular}

Source: Questionnaire forms 
Table 5. The respondents' E-readiness total score $(\mathrm{N}=117)$

\begin{tabular}{lc}
\hline Components & Total Scores \\
\hline Infrastructure and digital content & 0.45 \\
\hline Affordability & 0.50 \\
\hline ICTs skills & 0.40 \\
\hline E-readiness score & 0.45 \\
\hline
\end{tabular}

Source: Questionnaire forms

\subsection{The respondents' E-readiness total score}

Table (5) presents the respondents' E-readiness total score. The results show that the total E-readiness score is low (0.45); which is supported by the low scores of the three components: 0.45 for infrastructure and digital content, 0.50 for affordability, and 0.40 for the respondents' skills in ICTs.

\section{CONCLUSION}

Based on the research results, it can be concluded that extension personnel in Assiut governorate have a low E-readiness for utilizing ICTs in agricultural extension. The agricultural extension officials and policy makers should pay more attention to the three components of E-readiness for reaching high levels of it; ICTs infrastructure should be developed, constrains of utilizing ICTs in agricultural extension should be dealt with, and ICTs training courses should be presented to extension personnel in Assiut governorate to improve their ICT skills.

\section{REFERENCES}

Abdel-Maksoud, B. (2010). Developing a modified Delta N method for training needs assessment, Journal of Agricultural Extension and Rural Development, 2(10): 205-210.

Available

at: http://academicjournals.org/article/article1380034060 Ab del-Maksoud. pdf.

Abdel-Maksoud, B. and Abdel- Aal, A. (2007). Evaluations of extension personnel in Assiut governorate of their levels of knowledge and use and the degree of importance of information communication technology. African Crop Science Conference Proceedings, 8: 1307-1311. Available at: http://www.acss.ws/Upload/XML/Research/316. pdf.

Addom, B. (2004). E-Readiness assessment of seven higher education institutions in Ghana, Master Thesis, Cornell University, USA. Available at:
http://depot.gdnet.org/newkb/fulltext/Addom_Education_I nstitutions_in_Ghana.pdf.

Bilbao-Osorio, B., Dutta, S., Geiger, T. and Lanvin, B. (2014). The global information technology report, World Economic Forum, Geneva. Available at: http://www3.weforum.org/docs/WEF_GlobalInformation Technology_Report_2014.pdf.

Bui, T., Sankaran, S. and Sebastian, I. (2003). A framework for measuring national e-readiness, International Journal of Electronic Business, 1 (1): 3-22. Available at: http://ict4d.dk/uploads/general/A-Framework-forMeasuring-Natonal-E-Readiness.pdf

Economist Intelligence Unit (2009). E- Readiness ranking, the usage imperative, London. Available at: http://graphics.eiu.com/pdf/E-readiness\%20rankings.pdf

Gregg, J. and Irani, T. (2004). Use of information technology by county extension agents of the Florida cooperative extension service, Journal of Extension, 42 (3). Available at: http://www.joe.org/joe/2004june/rb2. php.

Jirlia, B. (2011). E-ready extensionist, Banaras Hindu University, India. Available at: http://agropedia.iitk.ac.in/content/e-ready-extensionist

Meera, S., Mangal, S., Muthuraman P, Arun Kumar, S., Sailaja B, Jyothi S. and Viraktamath B. (2010). Critical analysis of e-learning opportunities and e-readiness in the public extension system: empirical evidence from Tamil Nadu, Journal of Global Communication, 3 (2): 11-18. Available

at: http://agropedialabs.iitk.ac.in/i3r/sites/default/files/JGC\% 20ijor. pdf.

The World Bank (2005). E-Ready for what? E-readiness in developing countries: current status and prospects toward the millennium development goals. Washington, D.C. Available at: http://www.infodev.org/infodevfiles/resource/InfodevDocuments_3.pdf. 


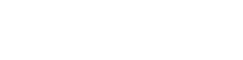

\section{قيلس الإستعاد الإكتروف اللعالمن بالجهاز الإشاهي بمحائلة أسيوا}

\author{
محمد فوزيسالملن عبد السلام، محمد محمد محمد عبد الغني
}

لأسيوط، وكذلك إنخفاض درجلت المكونات الثلاثة للإستعداد

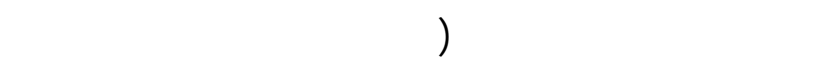
قدرة المبحوثين على تحمل تكالف الستخددل تالكنولوجيا المعلوملت والإتصالات في الإشياد الزراعي، ومهارات المبحوثن في إستخدلم تكنولوجيا المعلوملت والإتصالات).
يهوف هذا البهث إلى قيلس الإبستعداد الإلكتروني

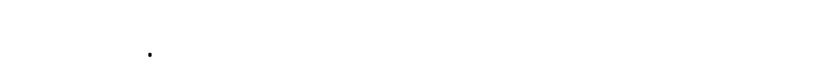
الدرلسة على IVV مبحوثاً يمثلون Y,7\% من إلجمالي العلملين بالجهاز الإششادي بمحلفة أسيوط والبالغ عددهم ro للإستعداد الإلكتروني للعلملين بالجهاز الإبشادي بمحلظة 